\title{
On support of commercial banks to financing of small- and medium-sized enterprises in Inner Mongolia
}

\author{
LIU Yue ${ }^{1, \text { a }}$ \\ ${ }^{1}$ Inner Mongolia University of Technology, Hohhot 010051, China \\ aliuyueimut@gmail.com
}

Keywords: Commercial banks; small- and medium-sized enterprises; financing support

\begin{abstract}
Since economic growth is slower than before, the number of small- and medium-sized enterprises (SMEs) in China grows rapidly. In order to obtain external financing, SMEs must use the power of commercial banks. This paper analyzes the present situation and existing problems of financing services of SMEs in Inner Mongolia from the perspective of commercial banks, and finds out that the current problems are as follows: relatively high bank loan interest rate, cumbersome credit flow, information asymmetry between banks and enterprises; lack of awareness from commercial banks to provide comprehensive service for SMEs, and insufficient financial products suitable for SMEs. Based on these questions, this paper comes up with suggestions from four aspects: business process, information disclosure, organizational structure and product innovation.
\end{abstract}

\section{Introduction}

Many SMEs have chosen to finance through commercial bank loans for a very long time, which have drawn more and more attention from commercial banks [1]. Innate constraints of SMEs make it difficult to win favor of commercial banks. Experts and scholars have been actively exploring approaches to effectively solve the problem of financing difficulties of SMEs. Considering analysis of reasons for the financing difficulties of SMEs, foreign scholars mainly elaborated from the theory of credit rationing, relational loan theory and information asymmetry theory [2-4], while domestic scholars mainly from the financial institutions and SMEs [5]. In addition, they also actively discuss how commercial banks should support SMEs financing. Status quo of the specific region must be taken into consideration, so that development strategies can be put forward accordingly. Only in this way, can a region develop in a real sense.

At present, there are few studies on SMEs in Inner Mongolia from the perspective of commercial banks as specific financial institutions. Therefore, in this paper, taking commercial banks, the specific financial institutions, as starting point, suggestions on how to enhance financing support for SMEs in Inner Mongolia are put forward. This is of great significance to improve and broaden the business of commercial banks and the healthy development of SMEs in Inner Mongolia.

According to China Financial Yearbook in 2015, statistics showed that the total amount of loans to SMEs had increased. By the end of 2013, total amount of loans (including bills discount) for medium-sized enterprises in China's financial institutions (including foreign capital) was 16124.525 billion RMB, with an increase of 1821.889 billion RMB compared with the beginning of 2013. The total loans of small enterprises (including discounted bills) amounted to 11994.922 billion RMB, with an increase of 1778.778 billion RMB compared with the beginning of 2013. According to annual survey report of China Small and Medium Enterprises Association in 2015, bank loans are still the main financing channels, $46.2 \%$ pursued financial supporting through bank loans, 25.7\% through private finance companies and $10.2 \%$ through network financing and small loan companies. Moreover, $82 \%$ of the companies considered loan supply inadequate, while other $18 \%$ believe that social loanable funds are sufficient, which reflects that overall market loan is in short supply [6-7].

Commercial banks in Inner Mongolia fully support the development of SMEs and try to provide better financial services for them. Inner Mongolia Bank has also developed the "central loan" business to support the development of SMEs and the implementation of national differences in financial support policies. At the end of 2014, the balance of the "central loan" reached 400 million 
$\mathrm{RMB}$, which supported the development such as food processing, grain and oil processing. Since the launch of "SME business model of new business funds supervision system" developed by Inner Mongolia Branch of Bank of China, relative business quality has been guaranteed from the perspective of scientific and technological innovation, and business structure has been deepened. By the end of the first quarter of 2015, customers adopting this new model reached 1093, accounting for $70.84 \%$ of the entire bank loan customers.

\section{Analysis of problems and causes of financing service provided by commercial banks}

Based on previous section, commercial banks actively explored and have made preliminary achievements to support the financing services for SMEs. But it must be recognized that the development of financial services for SMEs has many problems. This section gives a brief description of these problems and their causes in the development of financial services for SMEs.

Relatively high bank loan interest rate and cumbersome credit flow. According to the China Small and Medium Enterprises Association, statistics on SMEs financing situation show that SMEs generally believe that the financing cost they face is really high. To obtain bank loans, they must pay the cost of government administration and intermediary fees. Moreover, the commercial bank loan approval process is more cumbersome since many departments are involved [8].

Information asymmetry between banks and enterprises. In the loan business, the two sides, SMEs as the demander, and commercial banks as the provider, have learned difference information. If SMEs want to get financial support, they must make themselves honest enough to obtain trust of banks. At the same time, the financial system is not sound enough and financial information is not transparent enough, which made the bank's costs on risk control and regulatory increase. Therefore, whether SMEs can obtain the financial support from commercial banks mainly depends on whether the two sides have the same information.

Lack of awareness from commercial banks to provide comprehensive service for SMEs. The credit type of China's commercial banks mainly includes guarantee, mortgage, pledge and discount bills. Banks generally require SMEs to provide adequate and effective guarantee conditions, with most important way of guarantee real estate mortgage, which yet, is only single species. In Inner Mongolia, types of financial products suitable for SMEs are inadequate and far from being able to meet their financial needs. In addition, financial products presented by different banks are similar, which makes SMEs difficult to choose [9].

Insufficient financial products suitable for SMEs. What commercial banks seek is long-term development, and one of the key factors is to have high-quality customers to create profits and improve competitiveness. According to relational lending theory, large state-owned enterprises or high-quality private enterprises have maintained long-term cooperative relationship with banks, consequently, most commercial banks will target customers in these high-quality customers and maintain a high access threshold to SMEs, which restricts some SMEs from getting finance support in time. In addition, the degree of integration of services needs to be improved. For a long time, commercial banks have only focused on providing traditional deposit, loan and settlement business for SMEs. As for investment banking, consulting business and other integrated services have not been developed in the financial services yet.

\section{Suggestions on commercial banks providing financing services for SMEs in Inner Mongolia}

Investment increase from commercial banks to SMEs in Inner Mongolia has both theoretical and practical significance. But the realization of this goal is a systematic project and needs to be completed step by step. This section gives brief suggestions from four aspects: business process, information disclosure, organizational structure and product innovation.

Reduce financing costs and optimize the loan process. Commercial banks can introduce the "credit factory" model, that is, to adopt the "pipeline" mode of production, through which loan efficiency are improved by batch operation such as the design of financial products, credit review and approval, risk management and control processes. However, in the design and operation of this 
mode, we must pay attention that this model is originated overseas and in the introduction process needs to be improved to fit the actual situation in Inner Mongolia. In addition, commercial banks must improve their work efficiency and explore more efficient approval systems.

Enhance credit rating and scientific risk control. The existing rating system is difficult to assess risk and credit status of SMEs accurately, as a result, commercial banks in Inner Mongolia should improve the credit rating system indicators and risk management effectively. As the SMEs' information may be incorrect, which to some extent affects banks to evaluate SMEs' credit scientifically. Banks should also increase non-financial indicators as reference and supplementary means to reflect the credit level of SMEs, such as credit condition of actual controller or main operator. We can evaluate the actual controller or the principal operator's personal situation, investment or liability situation, personal credit situation, the organizational structure and corporate governance of the enterprise, the situation of the enterprise management personnel, the tax situation and the situation with the bank.

Set up franchise and improve professional skills. Commercial banks should, basing on specific needs, set up SMEs franchise and improve professional skills to achieve centralized and professional management. The construction of franchise institutions should fully integrate the risk management, marketing and product demand of SMEs and increase the skills of financial service personnel to enhance the staff's ability to ensure that the relevant policies are effectively executed, which manages the SMEs business in general. Commercial banks pointed out that small business loans should focus on the implementation of the "six mechanisms" announced by China Banking Regulatory Commission, namely the risk pricing mechanism, independent accounting mechanism, efficient loan approval mechanism, incentive and restraint mechanism, specialized personnel training mechanism and contract notification breach mechanism. Thus, the good strategic development and overall planning of SMEs can be insured. We can also set up SMEs services center which is responsible for the implementation of the head office of the ministry of SMEs to develop the planning and specialized management.

Accelerate product innovation and enrich types of service. With the gradual increase in the demand for financial services of SMEs, commercial banks' competitive advantage come out of comprehensive financial services innovation and expansion. Commercial banks should provide investment and financial management, information, asset restructuring, derivative finance tools and other comprehensive financial services. Firstly, commercial banks should familiarize SMEs with their various products to help them make the most appropriate choice. Secondly, to provide comprehensive financial services for the reform and development of SMEs, it is necessary for commercial banks to improve existing financial products or to transform them. Thirdly, commercial banks should develop new financial products to meet the diverse needs of different SMEs.

\section{Conclusion}

To sum up, this paper comprehensively examines the status quo of financial services for SMEs in Inner Mongolia from the perspective of commercial banks and draws the following conclusions: commercial banks have been actively exploring and trying to provide better financial services for SMEs. But it cannot be denied that many problems appeared in the development process. The existing problems are: relatively high bank loan interest rate, cumbersome credit flow, information asymmetry between banks and enterprises, lack of awareness from commercial banks to provide comprehensive service for SMEs, and insufficient financial products suitable for SMEs. Commercial banks should reduce the financing costs, optimize the credit process, set up franchise agencies, improve professional skills, accelerate product innovation and enrich types of financial service. Only in this way, can the financing difficulties of SMEs be solved effectively step by step.

\section{References}

[1] Gao D H. Study on the Financing Difficulties of Small and Medium-sized Enterprises in China [J]. Contemporary Economy, 2010, (6):30-31. 
[2] Bao G F. Research on the Current Situation and Countermeasures of Financing Business of Inner Mongolia Branch of Bank of Communications [D]. Inner Mongolia University, 2012.

[3] Eddie C, Conor M O. Bank Lending Constraints, Trade Credit and Alternative Financing during the Financial Crisis: Evidence from European Small and Medium-sized Enterprises [J]. Journal of Corporate Finance, 2014, 27: 173-193.

[4] James H. L, Stephen R, Ying Z. Experience, Age and Exporting Performance in UK Small and Medium-sized Enterprises [J]. International Business Review, 2015, 25: 806-819.

[5] Zhang W R. Study on the Credit Financing of Small and Medium-sized Enterprises by Chinese Commercial Banks [D]. University of International Business and Economics, 2014.

[6] Ye Y. Study on the Financing Modes of Small and Medium-sized Enterprises from the Perspective of Commercial Banks [D]. Beijing Jiaotong University, 2011.

[7] Zhang H Y. Financing Problems and Countermeasures of Small and Medium-sized Enterprises [J]. Journal of Anyang Teachers College, 2006, (4).11-12.

[8] Ramona R. Financing in Small and Medium-sized Enterprises: Case of the Baltic States [J]. Procedia-social and Behavioral Sciences, 2014, 150:116-125.

[9] Yost E. Small and Medium-sized Enterprises Financing in Transition Economies [J]. International Atlantic Economic Society, 2011(39):67-69. 